УдК 541.6

\title{
Influence of Aerobic bioprocessing \\ on Composition and Sorption Properties \\ of Berezovsky Brown Coal
}

\author{
Ivan P. Ivanov*a, \\ Margarita I. Teremovab, Anna O. Eremina ${ }^{a}$, \\ Valentina V. Golovina ${ }^{a}$, Svetlana A. Kozlova ${ }^{a}$, \\ Nikolay V. Chesnokov ${ }^{\mathrm{a}, \mathrm{b}}$ and Boris N. Kuznetsov ${ }^{\mathrm{a}, \mathrm{c}}$ \\ anstitute of Chemistry and Chemical Technology SB RAS \\ 50/24 Academgorodok, Krasnoyarsk, 660036, Russia \\ ${ }^{b}$ Krasnoyarsk Scientific Center SB RAS \\ Academgorodok, Krasnoyarsk, 660036, Russia \\ 'Siberian Federal University \\ 79 Svobodny, Krasnoyarsk, 660041, Russia
}

The influence of the aerobic impact by strains of bacteria Pseudomonas aeroginosa LMG 1242, Pseudomonas moorei and Delftia tsuruhatensis on the structure and the sorption properties of Berezovsky brown coal was studied. The properties of products of aerobic impact by these strains of bacteria and Acinetobacter calcoaceticus PMBC In-4833 were compared. It was shown that products of the aerobic impact by strains of bacteria Pseudomonas moorei and Delftia tsuruhatensis on brown coal are the most effective in the sorption of chromium from aqueous solutions.

Keywords: brown coal, bioprocessing, humic acids, chromium, sorption.

DOI: $10.17516 / 1998-2836-2016-9-1-49-59$.

(C) Siberian Federal University. All rights reserved

* Corresponding author E-mail address: ivanov@icct.ru 


\title{
Влияние аэробной биопереработки \\ на состав и сорбционные свойства \\ бурого угля Березовского месторождения
}

\author{
И.П. Иванов ${ }^{a}$, М.И. Теремова \\ А.О. Еремина ${ }^{a}$, В.В. Головина ${ }^{a}$, \\ С.А. Козлова ${ }^{\text {a }}$ Н.В. Чесноков ${ }^{\text {a, }}$, Б.Н. Кузнецов ${ }^{\text {a, }}$ \\ ${ }^{a}$ Институт химии и химической технологии СО РАН \\ Россия, 660036, Красноярск, Академгородок, 50/24 \\ ${ }^{6}$ Красноярский научный центр СО РАН \\ Россия, 660036, Красноярск, Академгородок, 50 \\ ${ }^{6}$ Сибирский федеральныий университет \\ Россия, 660041, Красноярск. пр. Свободный, 79
}

Изучено влияние аэробного воздействия штаммов бактерий Pseudomonas aeroginosa LMG 1242, Pseudomonas moorei и Delftia tsuruhatensis на состав и сорбиионные свойства бурого угля Березовского месторождения. Проведено сравнение свойств продуктов аэробной биопереработки бурого угля указанными штаммами бактерий и штаммом Acinetobacter calcoaceticus ВКПМ В-4833. Показано, что для сорбции ионов хрома из водных растворов наиболее эффективны продукты, полученные в результате биомодификации бурого угля штаммами бактерий Pseudomonas moorei и Delftia tsuruhatensis.

Ключевые слова: бурый уголь, биообработка, гуминовые кислоты, хром, сорбция.

\section{Введение}

Перспективным и экологически безопасным методом переработки углей низкой стадии метаморфизма (в частности бурых углей) является их биохимическая конверсия с использованием микроорганизмов [1]. Бурые угли имеют низкоконденсированную систему, в которой преобладают длинные алифатические цепи, а кислород входит в состав различных кислородсодержащих функциональных групп, и его содержание превышает 15-20 мас. \% [2]. Это позволяет эффективно использовать бурый уголь для получения газообразных, жидких и твердых облагороженных видов топлива, химического сырья, сорбентов и других синтетических продуктов $[3,4]$.

Многочисленными исследованиями [5-10] было показано, что микроорганизмы (грибы и бактерии) способны трансформировать углеродсодержащие материалы в ценные химические продукты, а также перспективное сырье для дальнейшего использования в термических процессах.

Для биопревращения бурого угля Александрийского месторождения (Константиновский разрез, Украина) были взяты микромицеты рода Penicillium, выделенные из угольных шламов ЦОФ «Трудовская» [11]. При биотрансформации бурого угля микромицетами практически не 
затрагивается минеральная составляющая угля, происходит частичное окисление угля сопровождается разрывом С-С-связей.

При биопереработке бурого угля штаммами бактерий Acinetobacter sp10, Pseudomonas sp2 и Pseudomonas sp57, выделенных из спонтанной микрофлоры бурого угля Бородинского месторождения, происходят значительные химические и структурные превращения органической массы угля [12-14]. В зависимости от продолжительности процесса атомное соотношение Н/С в продуктах биопереработки значительно изменяется, а именно увеличивается до 0,88 (в исходном угле 0,84) при продолжительности процесса 10 ч с последующим уменьшением до 0,85 при 20 ч, далее происходит нарастание Н/C до 0,88 (при продолжительности процесса 40 ч) и вновь уменьшение до 0,83 при 70 ч. Кривая зависимости атомного соотношения О/С проходит через один максимум: О/С увеличивается с 0,21 в исходном угле до 0,25 при продолжительности биопереработки 10 ч, с последующим снижением до 0,24 при 70 ч.

В [15] было показано, что биопереработка бурого угля штаммом бактерий Acinetobacter calcoaceticus BКПМ B-4833 при продолжительности процесса от 10 до 60 ч приводит к увеличению выхода гуминовых кислот до 30,5-32,4 мас. \% (в исходном угле - 24,8 мас. \%). Также отмечено, что в биомодифицированном в течение 10 ч буром угле количество фенольных гидроксильных групп возрастает по сравнению с исходным углем на 22,5 \% (с 2,76 до 3,38 мг-экв/г), карбоксильных на 24,8 \% (с 1,45 до 1,81 мг-экв/г) и карбонильных групп на 24,5 \% (с 0,69 до 0,86 мг-экв/г). Таким образом, эффективность биопереработки угля существенно зависит от применяемых культур микроорганизмов.

Целью настоящей работы являлось сопоставление состава и сорбционных свойств твердых продуктов биомодификации бурого угля Березовского месторождения штаммами бактерий Pseudomonas aeroginosa LMG 1242, Pseudomonas moorei и Delftia tsuruhatensis.

\section{Экспериментальная часть}

Для биомодификации использовали бурый уголь марки Б2 (измельченный до класса крупности 0-1 мм), добываемый Березовским филиалом ОАО «СУЭК». Средние значения технических характеристик ( \%) для этого угля: влажность $\left(\mathrm{W}_{\mathrm{t}}^{\mathrm{r}}\right)-32,8 \%$; зольность $\left(\mathrm{A}^{\mathrm{d}}\right)-$ 4,$9 ;$ содержание летучих веществ $\left(\mathrm{V}^{\mathrm{daf}}\right)-44,1 \%, \mathrm{C}^{\mathrm{daf}}-71,64 ; \mathrm{H}^{\mathrm{daf}}-5,44 ; \mathrm{S}_{\mathrm{t}}^{\mathrm{d}}-0,3 \%$; $\mathrm{N}^{\mathrm{daf}}-0,8$; выход суммарных гуминовых кислот $(\mathrm{HA})_{\mathrm{t}}^{\mathrm{daf}}-24,8$; выход свободных гуминовых кислот $(\mathrm{HA})_{\mathrm{f}}{ }^{\mathrm{daf}}-16,4$.

Биомодификацию бурого угля проводили в аэробных условиях с использованием жидкой культуры адаптированных к углю штаммов бактерий: Pseudomonas aeroginosa LMG 1242, Pseudomonas moorei u Delftia tsuruhatensis. Указанные бактерии относятся к грамотрицательным гетеротрофным микроорганизмам, имеют форму коротких палочек. Они используют кислород в качестве конечного акцептора электронов и растут при температуре $20-35{ }^{\circ} \mathrm{C}$ [16].

Аэробную биопереработку бурого угля осуществляли в реакторе (объемом 3 л) с механическим перемешиванием (450 об/мин), с аэрацией воздухом, при температуре 25-30 ${ }^{\circ} \mathrm{C}$. Инокулят адаптированных бактерий в количестве 200 мл вносили в реактор, содержащий 100 г бурого угля и 800 мл воды. Аэробную переработку бурого угля проводили в течение 20 ч при pH среды 7,0. Продукты биомодификации бурого угля сушили в сушильном шкафу камерного типа с принудительной вентиляцией при температуре $80{ }^{\circ} \mathrm{C}$ до постоянной массы. 
Жидкую культуру адаптированных и активных бактерий получали по схеме: 1) перенос музейной культуры бактерий, хранившейся в лиофилизированной форме, в жидкую культуру и размножение; 2) перевод бактерий из жидкой культуры на агаризованную твердую среду для кратковременного хранения и использования в качестве инокулята при наращивании партий массовой культуры; 3) адаптация бактерий к росту на буром угле, регулярное получение образцов жидкой культуры и последующее использование в качестве инокулята при проведении экспериментов по биопереработке бурого угля.

Определение выхода летучих веществ $\mathrm{V}^{\mathrm{daf}}$ и гуминовых кислот (суммарных (HA) ${ }_{\mathrm{t}}^{\mathrm{daf}}$ и свободных $(\mathrm{HA})_{\mathrm{f}}^{\mathrm{daf}}$ ) в исходном угле и продуктах его биомодификации проводили по стандартным методикам, описанным в $[17,18]$. Содержание углерода, водорода определяли на автоматическом анализаторе Flash EA-1112, Thermo Quest. Проводили расчет выхода летучих веществ, гуминовых кислот (суммарных и свободных), содержания углерода и водорода на сухую беззольную массу (daf) исследуемых образцов.

Регистрацию ИК-спектров исходного угля и продуктов его биопереработки осуществляли на ИК-Фурье-спектрометре Tensor 27 (Bruker, Германия) в области 4000-400--1. Обработка спектральной информации проведена с использованием пакета программ OPUS, версия 5.5. Расшифровку ИК-спектров выполняли в соответствии с [19].

Образцы для получения спектров готовили в виде таблеток в матрице бромистого калия. Условия приготовления образцов (время перемешивания с бромистым калием, давление прессования, время вакуумирования) одинаковы. Концентрация вещества в матрице была постоянна и составляла 3 мг/1 г $\mathrm{KBr}$.

Изучение сорбции ионов хрома из водных растворов на исходном угле и продуктах его биопереработки проводили по методике, описанной в [20]. Образцы вышеуказанных материалов (массой 1,00 г) помещали в колбы с притертыми пробками со 100 мл водного раствора бихромата калия, встряхивали с малой интенсивностью в течение 48 ч. Водный раствор отделяли центрифугированием, определяли остаточное содержание ионов хрома. Для испытаний использовали водные растворы бихромата калия с концентрацией по хрому от 50 до 400 мг/л, pH исходных растворов поддерживали на уровне 2,5 [21, 22]. Расчет сорбции ионов хрома на продуктах биопереработки угля проводили по формуле

$$
\mathrm{A}=\frac{\left(\mathrm{C}_{\mathrm{o}}-\mathrm{C}_{\mathrm{p}}\right) \cdot \mathrm{V}}{m}
$$

где $\mathrm{A}$ - сорбция ионов хрома (мг/г); $\mathrm{C}_{\mathrm{o}}$ и $\mathrm{C}_{\mathrm{p}}$ - концентрации ионов хрома в исходном и равновесном растворах (мг/л); $\mathrm{V}$ - объем хромсодержащего раствора (л); $m$ - навеска сухого продукта биомодификации угля (г).

Контроль за содержанием хрома в исходных растворах и в растворах после отделения образцов осуществляли по традиционной методике с дифенилкарбазидом в водной среде [23]. На углеродсодержащих материалах возможно восстановление хрома со степенью окисления +6 до хрома со степенью окисления +3 [24]. Поэтому для определения малых количеств хрома (III) в присутствии хрома (VI) отделяли хром (III) из раствора в виде гидроксида (аммиаком), как описано в работе [23]. После растворения осадка и окисления хрома до степени окисления +6 определяли его также с дифенилкарбази- 
дом. Для приготовления водных растворов применяли бихромат калия квалификации «ХЧ».

\section{Результаты и обсуждение}

Технические характеристики продуктов биомодификации бурого угля (БМУ) Березовского месторождения штаммами бактерий Pseudomonas aeroginosa LMG 1242 (БМУ-1), Pseudomonas moorei (БМУ-2) и Delftia tsuruhatensis (БМУ-3) приведены в таблице.

В процессе аэробной биопереработки бурого угля штаммами вышеуказанных микроорганизмов отмечено снижение содержания углерода в полученных продуктах БМУ по сравнению с исходным углем на 4-5 отн. \%, а также уменьшение содержание водорода на 6-11 отн. \%. Одновременно с этим наблюдается увеличение зольности продуктов БМУ до 6,17,5 мас. \% (при зольности исходного угля 4,9 мас. \%), а также увеличение выхода летучих веществ на 15-17 отн. \%. Таким образом, полученные результаты указывают на снижение степени углефикации бурого угля под действием микроорганизмов. Наряду со снижением содержания углерода и водорода происходит увеличение содержания кислородсодержащих фрагментов в угольной матрице - отмечено увеличение атомного соотношения О/С в продуктах БМУ на 17-23 отн. \% по сравнению с исходным углем.

Этот факт согласуется с увеличением выхода гуминовых кислот, как суммарных (в 1,721,99 раза), так и свободных (в 1,42-1,58 раза), в продуктах БМУ. Однако отмечено некоторое относительное снижение доли свободных гуминовых кислот в суммарном выходе гуминовых кислот до 0,50-0,55 по сравнению с исходным углем $(0,66)$. По-видимому, свободные гуминовые кислоты, образующиеся при биомодификации угля, распадаются на более низкомолекулярные продукты и в первую очередь являются питательной средой для штаммов бактерий.

Для сравнения в таблице представлены также основные свойства продукта биопереработки бурого угля штаммом бактерий Acinetobacter calcoaceticus BКПМ B-4833 (БМУ-4), описанные ранее в работе [15]. При биопереработке бурого угля штаммами Pseudomonas aeroginosa LMG 1242, Pseudomonas moorei и Delftia tsuruhatensis выход суммарных и свободных гумино-

Таблица. Технические характеристики продуктов биомодификации бурого угля Березовского месторождения штаммами различных бактерий

\begin{tabular}{|c|c|c|c|c|c|c|c|c|}
\hline \multirow{2}{*}{$\begin{array}{c}\text { Штамм бактерий (образец } \\
\text { продукта) }\end{array}$} & \multirow{2}{*}{$\begin{array}{c}\mathrm{A}^{\mathrm{d}}, \\
\text { мac. } \%\end{array}$} & \multirow{2}{*}{$\begin{array}{c}\mathrm{V}^{\text {daf }} \\
\text { Mac. } \%\end{array}$} & \multirow{2}{*}{$\begin{array}{l}\mathrm{C}^{\text {daf }}, \\
\text { Mac. } \%\end{array}$} & \multirow{2}{*}{$\begin{array}{l}\mathrm{H}^{\mathrm{daf}}, \\
\text { Mac. } \%\end{array}$} & \multicolumn{2}{|c|}{$\begin{array}{c}\text { Атомные } \\
\text { соотношения }\end{array}$} & \multirow{2}{*}{$\begin{array}{c}(\mathrm{HA})_{\mathrm{t}}{ }^{\mathrm{daf}}, \\
\text { мac. } \%\end{array}$} & \multirow{2}{*}{$\begin{array}{c}(\mathrm{HA})_{\mathrm{f}}{ }^{\mathrm{daf}}, \\
\text { мac. } \%\end{array}$} \\
\hline & & & & & $\mathrm{H} / \mathrm{C}$ & $\mathrm{O} / \mathrm{C}$ & & \\
\hline- & 4,9 & 44,1 & 71,64 & 5,44 & 0,91 & 0,229 & 24,8 & 16,4 \\
\hline $\begin{array}{l}\text { Pseudomonas aeroginosa } \\
\text { LMG } 1242 \text { (БМУ-1) }\end{array}$ & 6,1 & 51,7 & 68,37 & 4,84 & 0,85 & 0,273 & 42,5 & 22,9 \\
\hline $\begin{array}{l}\text { Pseudomonas moorei } \\
\text { (БМУ-2) }\end{array}$ & 7,5 & 50,3 & 68,42 & 5,12 & 0,90 & 0,279 & 49,2 & 24,7 \\
\hline $\begin{array}{l}\text { Delftia tsuruhatensis } \\
\text { (БМУ-3) }\end{array}$ & 6,8 & 50,8 & 67,94 & 4,95 & 0,87 & 0,288 & 42,6 & 23,3 \\
\hline $\begin{array}{l}\text { Acinetobacter calcoaceticus } \\
\text { ВКПМ В-4833 } \\
(\text { БМУ-4) }\end{array}$ & 5,8 & 51,4 & 71,31 & 4,85 & 0,82 & 0,235 & 30,8 & 19,0 \\
\hline
\end{tabular}


вых кислот на 38-60 и 23-36 отн. \% выше, а атомное соотношение O/C на 19-23 отн. \% выше, чем при использовании штамма бактерий Acinetobacter calcoaceticus ВКПМ В-4833.

Анализ ИК-спектров, представленных на рис. 1, показывает, что исходный бурый уголь и продукты его биомодификации штаммами различных микроорганизмов имеют аналогичную спектральную картину.

Полосу поглощения (п.п.) с максимумом $1165-^{-1}$ относят к валентным колебаниям С-О групп фенолов [25], 1270--1 - к колебаниям карбоксильных групп [26] или ароматических эфирных группировок $\mathrm{C}_{6} \mathrm{H}_{5}-\mathrm{O}-\mathrm{C}$ [25], 1380-1 - к $-\mathrm{CH}_{3}$-группам в алифатических цепях [25, 27], $1613-^{-1}-$ к валентным колебаниям $\mathrm{C}=\mathrm{C}$-ароматического кольца [25-27], $\approx 1700-^{-1}-$ к валентным

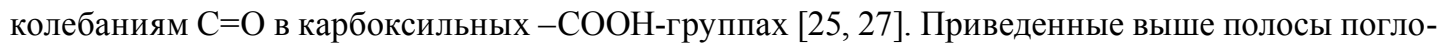
щения характерны для всех указанных образцов.

Наличие в спектрах полос поглощения средней интенсивности с максимумами 2855 и $2923-^{-1}$ отвечают валентным колебаниям $-\mathrm{CH}_{2}$-групп в боковых алифатических цепях, с максимумами 2962 и $2870-^{-1}$ - валентным колебаниям - $\mathrm{CH}_{3}$-групп, по-видимому, входящих в состав гуминовых кислот.

Широкая интенсивная п.п. с максимумом $3424-^{-1}$ обусловлена валентными колебаниями связанной воды, а также различными типами гидроксильных групп, связанных водородными связями. Полоса поглощения с максимумом $1616-^{-1}$, на наш взгляд, является суперпозицией п.п.

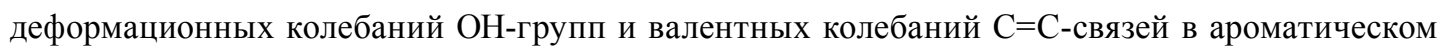
кольце [28]. Косвенным подтверждением последнего служит наличие в спектрах п.п. с максимумом 3030--1 и триплета полос поглощения с максимумами 750, 817 и $866-^{-1}$, относящихся к валентным колебаниям и внеплоскостным деформационным колебаниям ароматических С-Hсвязей соответственно.

По интегральной интенсивности п.П., характеризующих валентные колебания $-\mathrm{CH}_{2}$-и - $\mathrm{CH}_{3}$-групп, продукты биомодификации угля можно расположить в следующий ряд: БМУ-3 > БМУ-2 > БМУ-1 = БМУ-4 (поскольку величина интегралов отличается незначительно). Таким

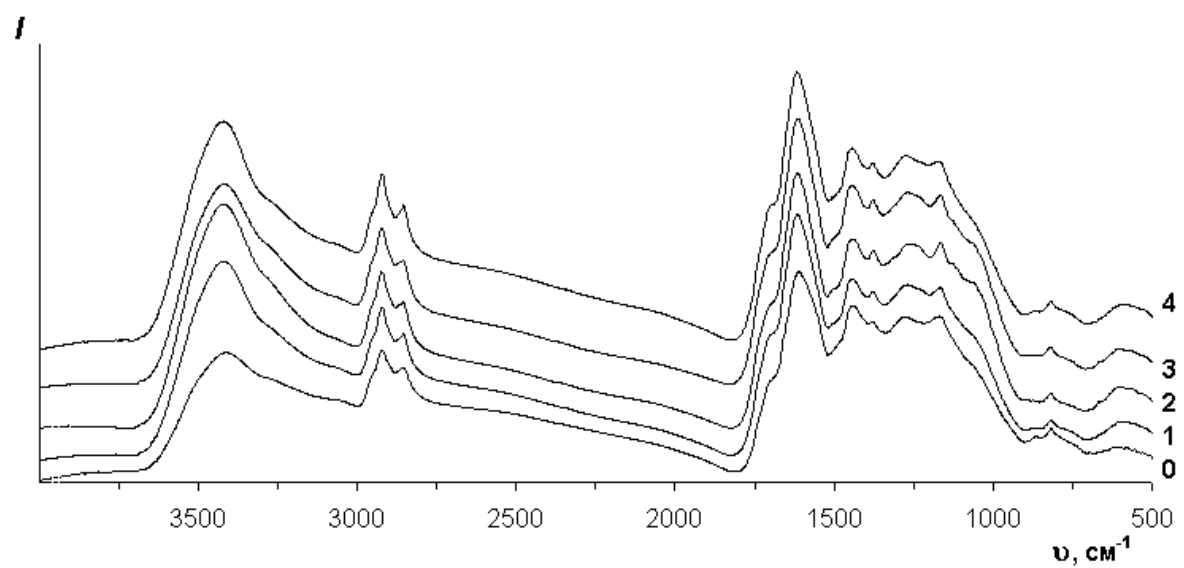

Рис. 1. ИК-спектры исходного бурого угля Березовского месторождения (0) и продуктов его биомодификации штаммами бактерий: 1 - Pseudomonas aeroginosa LMG 1242 (БМУ-1); 2 - Pseudomonas moorei (БМУ-2); 3 - Delftia tsuruhatensis (БМУ-3); 4 - Acinetobacter calcoaceticus BКПМ В-4833 (БМУ-4) 
образом, ИК-спектры исходного бурого угля и продуктов его биомодификации принципиально не отличаются, что свидетельствует о близости их химической структуры.

На рис. 2 приведены изотермы сорбции ионов хрома (VI) продуктами БМУ. Изотермы сорбции ионов хрома (VI) продуктами БМУ штаммами бактерий Pseudomonas aeroginosa LMG 1242, Pseudomonas moorei и Delftia tsuruhatensis (кривые 1-3) отличаются друг от друга, а также от изотермы сорбции на продукте БМУ-4 штаммом бактерий Acinetobacter calcoaceticus ВКПМ B-4833 (кривая 4) исключительно лишь по величине сорбционной емкости. Так, в области равновесных концентраций ионов хрома (VI) до 200 мг/л образцы БМУ-1, БМУ-2 и БМУ-3 превосходят по сорбции хрома образец БМУ-4 в 1,2-1,8 раза. Образец БМУ-4 характеризуется одинаковой сорбцией с образцами БМУ-1 (12 мг/Г) и БМУ-2 (16 мг/Г) при равновесных концентрациях ионов хрома (VI) 210 и 225 мг/л соответственно.

Наблюдаемое различие в величинах сорбционной емкости изученных образцов коррелирует как с увеличением атомного соотношения О/С: 0,235 (БМУ-4) $<0,270$ (БМУ-1) < 0,279 $($ БМУ-2) $<0,288$ (БМУ-3), так и с увеличением выхода суммарных гуминовых кислот от 30,8 до 42,5-49,2 мас. \% и увеличением выхода свободных гуминовых кислот от 19,0 до 22,9-24,7 мас. \% для БМУ-4 и изученных образцов соответственно (табл.).

В работе [26] рост сорбции металлов $\left(\mathrm{Pb}^{2+}\right.$ и $\left.\mathrm{Cd}^{2+}\right)$ на угле связывают прежде всего с ростом содержания карбоксильных групп (п.п. 1700--1) в образцах. В нашем случае п.п. с максимумом $1700-^{-1}$ (рис. 1) является лишь слабо выраженной полосой (плечом) интенсивной п.п. ароматического кольца (1613--1), поэтому судить об эффективности сорбционного процесса как о следствии роста содержания карбоксильных групп здесь не представляется возможным (слишком незначительно различие).

Изотермы сорбции ионов хрома (VI) на образцах БМУ-1, БМУ-2 и БМУ-3 могут быть описаны с высокой достоверностью $\left(\mathrm{R}^{2}=0,99\right)$ уравнением Фрейндлиха $\left(\mathrm{A}=\alpha \mathrm{C}^{\frac{1}{n}}\right)$ [29]: зависимости $\lg \mathrm{A}-\lg \mathrm{C}_{\mathrm{p}}$ имеют прямолинейный характер (рис. 3). Из вышеуказанных уравнений был рассчитан расход продуктов БМУ (рис. 4) для снижения концентрации ионов хрома (VI) в растворе

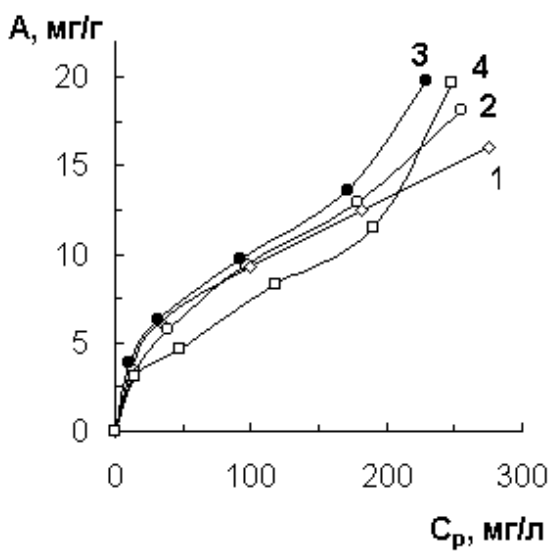

Рис. 2. Изотермы сорбции (А) ионов хрома (VI) продуктами биомодификации бурого угля штаммами бактерий: 1 - Pseudomonas aeroginosa LMG 1242 (БМУ-1); 2 - Pseudomonas moorei (БМУ-2); 3 - Delftia tsuruhatensis (БМУ-3); 4 - Acinetobacter calcoaceticus ВКПМ В-4833 (БМУ-4); $C_{p}$ - равновесная концентрация ионов хрома (VI) в растворе 


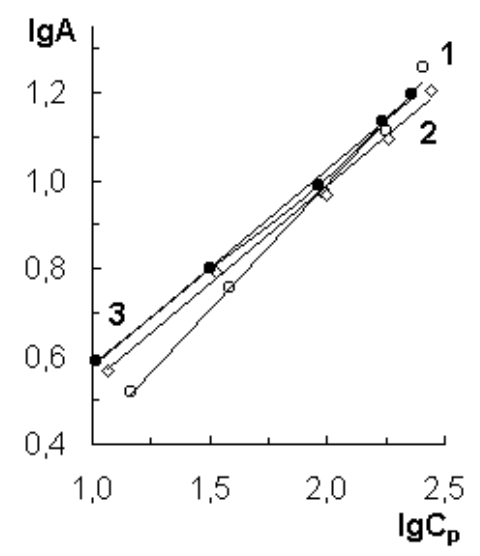

Рис. 3. Зависимость $\lg \mathrm{A}$ от $\lg \mathrm{C}_{\mathrm{p}}$ для сорбции (А, мг/г) ионов хрома (VI) продуктами биомодификации бурого угля штаммами бактерий: 1 - Pseudomonas aeroginosa LMG 1242; 2 - Pseudomonas moorei; 3 - Delftia tsuruhatensis; $\mathrm{C}_{\mathrm{p}}$ - равновесная концентрация ионов хрома в растворе, мг/л
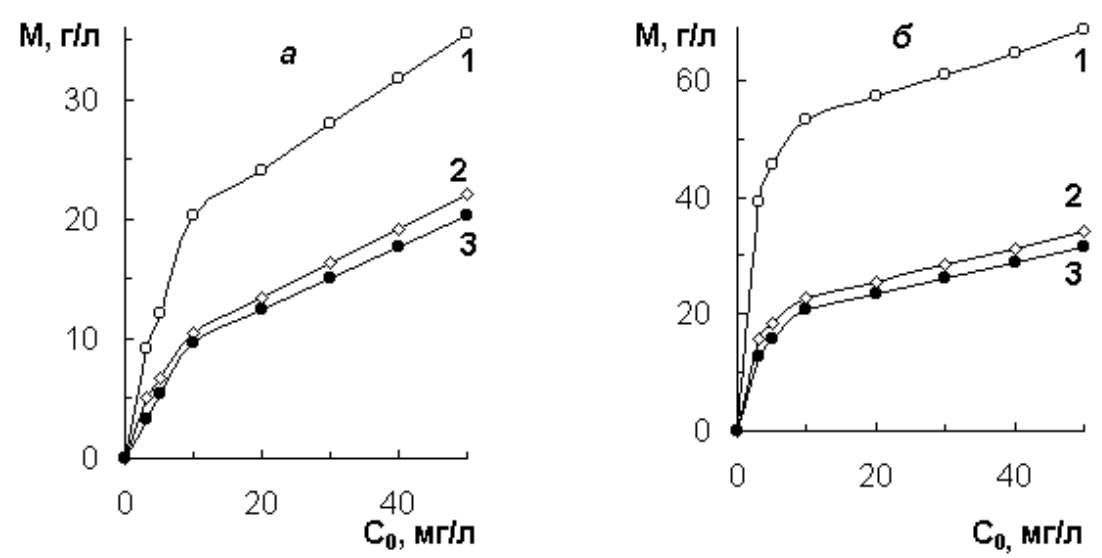

Рис. 4. Влияние исходной концентрации $\left(\mathrm{C}_{\mathrm{o}}\right)$ ионов хрома (VI) на расход (M) продуктов биомодификации бурого угля штаммами бактерий: 1 - Pseudomonas aeroginosa LMG 1242; 2 - Pseudomonas moorei; 3 - Delftia tsuruhatensis), обеспечивающий удаление ионов хрома (VI) в растворе до уровня $0,5 \mathrm{mг} /$ л

до уровня 0,5 мг/л, что соответствует предельно допустимой концентрации ионов хрома в воде водоемов [30]. Результаты, представленные на рис. 4, показывают, что для достижения требуемого снижения концентрации ионов хрома до 0,5 мг/л (0,1 мг/л) расход продукта БМУ-1 в 1,2-1,9 $(1,4-2,4)$ и $1,3-2,1(1,6-2,6)$ раза выше, чем расход продуктов БМУ-2 и БМУ-3 соответственно. Продукт БМУ-3 отличается от продукта БМУ-2 меньшим расходом, но не более чем на 8-9 \%. Значит, для сорбции ионов хрома наиболее эффективными и требующими меньшего расхода являются продукты БМУ-2 и БМУ-3, полученные в результате биомодификации бурого угля Березовского месторождения штаммами бактерий Pseudomonas moorei и Delftia tsuruhatensis. Однако при очистке высоконцентрированных водных растворов, содержащих более 50 мг/л ионов хрома (VI), для снижения расхода продуктов биомодификации бурого угля следует проводить их предварительное разбавление.

$$
-56-
$$




\section{Выводы}

При аэробной переработке бурого угля Березовского месторождения штаммами бактерий Pseudomonas aeroginosa LMG 1242, Pseudomonas moorei u Delftia tsuruhatensis наблюдалось снижение степени углефикации бурого угля. Отмечено снижение содержания углерода в полученных продуктах биомодификации на 4-5 отн. \%, увеличение атомного соотношения О/C на 17-23 отн. \%, увеличение выхода гуминовых кислот, как суммарных (в 1,72-1,99 раза), так и свободных (в 1,42-1,58 раза), по сравнению с исходным углем.

Показано, что продукты биомодификации бурого угля вышеуказанными микроорганизмами имеют близкую химическую структуру, как и сам бурый уголь, а также продукты его биомодификации штаммом бактерий Acinetobacter calcoaceticus BКПM B-4833.

Установлено, что продукты биомодификации бурого угля могут быть использованы для сорбции ионов металлов, в частности ионов хрома (VI), из водных растворов в интервале концентраций до 50 мг/л. Наиболее эффективны для сорбции ионов хрома продукты биомодификации бурого угля штаммами бактерий Pseudomonas moorei и Delftia tsuruhatensis. При исходной концентрации хрома (VI) 10-50 мг/л достигнуто снижение его концентрации до уровня 0,5 мг/л при расходе продуктов биомодификации бурого угля не более 20 г/л.

\section{Список литературы}

Ivanov I.P. Main trends in the biotechnological processing of coals: A review. Solid Fuel Chemistry 2007. Vol. 41. N 1. P. 3-10.

Гюльмалиев А.М., Головин Г.С., Гладун Т.Г. Теоретические основы химии угля. М.: Изд-во Мос. горн. ун-та, 2003. 556 c.[Gyul'maliev A.M., Golovin G.S., Gladun T.G. The theoretical basis of coal chemistry. Moscow: Publ. House Moscow mining university, 2003. 556 p. (In Russ.)]

3. Фундаментальные основы комплексной переработки углей КАТЭКа для получения энергии, синтез-газа и новых материалов с заданными свойствами / В.Ф. Шабанов, Б.Н. Кузнецов, М.Л. Щипко и др. Интеграционные проекты СО РАН. Вып. 3. Новосибирск: Изд-во СО PAH, 2005. 219 c. [Fundamental basis of KATEK coals complex processing with manufacture of energy, syn-gas and materials with desired properties /V.F.Shabanov, B.N.Kuznetsov, M.L.Shchipko et. al. Integration projects of SB RAS, is. 3. Novosibirsk: Publ. House SB RAS, 2005. 219 p. (In Russ.)]

4. Глубокая переработка бурых углей с получением жидких топлив и углеродных материалов /Б.Н. Кузнецов, Т.Г. Шендрик, М.Л. Щипко и др.; отв. ред. Г.И. Грицко. Интеграционные проекты СО РАН. Вып. 36. Новосибирск: Изд-во СО РАН, 2012. 212 с. [Deep processing of brown coals to liquid fuels and carbon materials /B.N.Kuznetsov, T.G.Shendrik, M.L.Shchipko et. al.; Ex. ed. G.I.Gritsko. Integration projects of SB RAS, is. 36. Novosibirsk: Publ. House SB RAS, 2012. 212 p. (In Russ.)]

5. Ackerson M.D., Johnson N. L., Le M. et al. Biosolubilization and liquid fuel production from coal. Appl. Biochem. Biotechnol. 1990. Vol. 24/25. P. 913-928.

6. Camara A., Laborda F., Monistrol I.F. Biological processing of fossil fuels. Fuel Proc. Technol. 1997. Vol. 52. P. 1-277.

7. Catcheside D.E.A., Ralph J.P. Biological processing of coal. Appl. Microbiol. Biotechnol. 1999. Vol. 52. P. 16-24. 
8. Fakoussa R. M., Hofrichter M. Biotechnology and microbiology of coal degradation. Appl. Microbiol. Biotechnol. 1999. V. 52. P. 25-40.

9. Sekholova L.M., Igbinigie E.E., Cowan A.K. Biological degradation and solubilisation of coal. Biodegradation 2013. Is.24. N3. P. 305-318.

10. Кляйн О.И., Куликова Н.А., Константинов А.И. и др. Трансформация гуминовых веществ высокоокисленного бурого угля базидиальными грибами Trametes hirsuta и Trametes тахіта. Прикл. биохимия и микробиология. 2013. Т. 49. №3. С. 292-300. [Klyajn O.I., Kulikova N.A., Konstantinov A.I. et al. Transformation of humic substances of high-oxidized brown coal by bazidial micromycetes Trametes hirsuta and Trametes maxima. Appl. Biochem. Microbiol. 2013. Vol. 49. N3. P. 292-300 (In Russ.)]

11. Шевкопляс В.Н. Структурно-химическая трансформация низкосортного угля микромицетами: [Электронный ресурc]. URL: http://www.eco-mir.net/show/362 (12.04.2001). [Shevkoplyas V.N. Structure and chemical transformation of low-graded coal by micromycetes: (Electronic resource). URL: http://www.eco-mir.net/show/362 (12.04.2001). (In Russ.)]

12. Golovin Yu.G., Shchipko M.L., Kuznetsov B.N. et al. The study of Kansk-Achinsk lignite bioconversion products. Fuel 1996. V.75. N2. P. 139-143.

13. Ivanov I.P., Sudakova I.G., Kuznetsov B.N. Manufacture of briquetted and granulated fuels from lignite with biobinders and heated die. Chemistry for sustainable development 2003. N 6. P. 847853 .

14. Ivanov I.P. Effect of the process conditions of aerobic bioconversion on the characteristics of biologically processed brown coals. Solid Fuel Chemistry 2007. Vol. 41. N 2. P. 75-78.

15. Иванов И.П., Теремова М.И., Еремина А.О. и др. Аэробная переработка бурого угля штаммом Acinetobacter calcoaceticus. Журнал Сиб. федер. ун-та 2014. N 2. P. 209-220. [Ivanov I.P., Teremova M.I., Eremina A.O. et al. Aerobic processing of brown coal by strain of Acinetobacter calcoaceticus. Journal of Siberian Federal University. Chemistry 2014. N 2. P. 209-220. (In Russ.)]

16. Bergey's manual determinative bacteriology. Editor-in-chief John G.Holt. $9^{\text {th }}$ ed. Baltimore: Williams \& Wilkins, 2000. 787 p.

17. ГОСТ 6382-2001 (ИСО 562-98, ИСО 5071-1-97). Топливо твердое минеральное. Методы определения выхода летучих веществ. [GOST 6382-2001 (ISO 562-98, ISO 5071-1-97). Solid mineral fuel. Methods for determining the efficiency of volatile substances. (In Russ.)]

18. ГОСТ 9517-94. Топливо твердое. Методы определения выхода гуминовых кислот. [GOST 9517-94. Solid fuel. Methods for determining the efficiency of humic acids. (In Russ.)]

19. Беллами Л. Новые данные по ИК-спектроскопии сложных молекул. М.: Мир, 1971. 365 c. [Bellamy L. New data on IR spectroscopy of complex molecules. Moscow: Mir, 1971. 365 p. (In Russ.)]

20. Пономарев В.Г., Иоакимис Э.Г., Монгайт И.Л. Очистка сточных вод нефтеперерабатывающих заводов. М.: Химия, 1985. 256 с. [Ponomarev V.G., Ioakimis A.G., Mongajt I.L. The purification of wastewater of oil refineries. Moscow: Khimiya, 1985. 256 p. (In Russ.)]

21. Нистратов А.В., Клушин В.Н., Ерофеева В.Б. Разработка процесса очистки от хрома (VI) сточных вод гальванического производства активным углем на торфополимерной основе. Успехи в химии и химической технологии 2012. T.XXVI. №10(139). C.94-98. [Development of the purification process of chromium (VI) wastewater electroplating by activated charcoal on peat and 
polymer basis. Advances in chemistry and chemical technology 2012. Vol. XXVI. N 10 (139). P. 94-98. (In Russ.)]

22. Veena Devi B., Jahagirdar A.A., Zulfigar Ahmed M.N. Adsorption of chromium on activated carbon prepared from coconut shell. Int. J. Eng. Res. Appl. 2012. Vol. 2. Is.5. P. 364-370.

23. Марченко 3. Фотометрическое определение элементов / Пер. с польск. И.В.Матвеевой и А.А.Немодрука. Под ред. Ю.А.Золотова. М.: Мир, 1971. 501 с. (Marchenko Z. Photometric determination of elements. Translated from Polish by I.V.Matveeva and A.A.Nemodruk. Ed. by Yu.A.Zolotov. Moscow: Mir, 1971. 501 p. (In Russ.)]

24. Воропанова Л.А., Рубановская С.Г. Использование древесных опилок для очистки сточных вод от хрома. Химическая промышленность 1998. №1. C.22-24. [Voropanova L.A., Rubanovskaya S.G. Application of sawdust for wastewater purification from chromium. Khimicheskaya promushlennoct' 1998. N 1. P. 22-24. (In Russ.)]

25. Guang Xiong, Yunsheng Li, Lijun Jin, Haoquan Hu. In situ FT-IR spectroscopic studies on thermal decomposition of the weak covalent bonds of brown coal . J. Analytical and Applied Pyrolysis 2015. N 115. P. 262-267.

26. Zhen Chen, Lijian Ma, Shuqiong Li, et. al. Simple approach to carboxyl-rich materials through low-temperature heat treatment of hydrothermal carbon in air. Applied Surface Science 2011. N 257. P. 8686-8691.

27. Gregory N. Okolo, Hein W.J.P. Neomagus, Raymond C. Everson, et.al. Chemical-structural properties of South African bituminous coals: Insights from wide angle XRD-carbon fraction analysis, ATR-FTIR, solid state ${ }^{13} \mathrm{C}$ NMR, and HRTEM techniques. Fuel 2015. N 158. P. 779-792.

28. Brown J.K. The infrared spectra of coals. J. Chem. Soc. 1955. N 3. P. 744-752.

29. Кельцев Н.В. Основы адсорбционной техники. М.: Химия, 1984. 592 с. [Kel'tsev N.V. Background of adsorptive technique. Moscow: Khimiya, 1984. 592 p. (In Russ.)]

30. Беспамятнов Г.П., Кротов Ю.А. Предельно-допустимые концентрации химических веществ в окружающей среде. Л.: Химия, 1985. 528 с. [Bespamyatnov G.P., Krotov Yu.A. Maximum allowable of chemical substances at environment. Leningrad: Khimiya, 1985. 528 p. (In Russ.)] 